\title{
Replacing place in planning history
}

\section{Sustitución del lugar en la historia de la planificación}

DOI: $10.46932 / \mathrm{sfjdv} 2 \mathrm{n} 5-134$

Received in: Oct 1st, 2021

Accepted in: Dec 30th, 2021

\author{
Lineu Castello \\ $\mathrm{PhD}$ in ARCHITECTURE \\ UFRGS-Federal University of Rio Grande do Sul, Porto Alegre, Brazil \\ Rua Marques de Pombal 1385/201 90540-001 PORTO ALEGRE \\ E-mail: lincastello@terra.com.br
}

\begin{abstract}
Variations are due to happen in the course of Planning History, though there has been an unusual outburst of changes in recent times. Two factors seem to be at the outset of these changes: the crucial growth of global urbanization; and the actual tendency for cities presenting a complex of 'place' centralities. Undoubtedly, central to alterations in Planning History are the special conditions of contemporary society, with almost $80 \%$ of whose members living in urbanized environments. But next to it comes the extraordinary increase in the production of newly invented 'places' under the most diverse forms: entertainment places, themed malls, revamping of historical settings, and so on. This pervading tendency led to changes in planning attitudes, seen as historical in face of their global claims. However, many of the innovative theoretical issues now linked to the concept of place have not been thoroughly examined in the Planning area so far. Additionally, the concept is now engrossing the research interests of other disciplines, which results in important contributions being introduced to its foundational aspects, hence, establishing a transdisciplinary condition to its essence. In fact, planning theory seems now ripe to 'replace' its prevalent understanding of place. This paper intends to suggest some of the directions to follow in such an attempt. Methodologically, it will pursue the directions set by three types of conflicts generated by the variations: controversies, contrasts, and challenges.

To approach the variations in terms of the controversies implies to realize the duality in the roles places can perform in today's societal behaviours: a functional as well as an existential one. Indeed, for some scholars, the new invented places of today are appropriated as new places of urbanity, leading to think that we are on the brink of a situation where the perception of place can influence the perception of 'urbanity' - urbanity understood as that unique quality forwarded by cities to their citizens in terms of communication and sociability - ultimately entailing new ways of enjoying the urbanity cities have to offer. Contrasts associated to the variations bring to light a duality present in the Planning discipline itself. Previously, the discipline had that the sense of place would derive exclusively from society's practices, emerging from them as a social construction, whereas today, besides being a social construction, place is also regarded as an economic construction. This is a condition that sometimes exacerbates inherent social contrasts, producing cities dotted with fragments of exception believed to act upon the urban structure as disintegrative factors evidencing latent differences. Finally, to approach the variations in terms of their challenges will direct the focus towards the planning decisions city's administrators are faced to take when settling to embark on the placemaking + placemarketing game - or not - a challenge cities increasingly are compelled to adhere to, often at the risk of engaging on demanding competitive practices.
\end{abstract}

Keywords: Place theory, Urbanity, Planning history, Environmental perception. 


\section{RESUMEN}

Las variaciones se suceden en el curso de la historia de la planificación, aunque en los últimos tiempos se ha producido un estallido inusual de cambios. Dos factores parecen estar en el origen de estos cambios: el crecimiento crucial de la urbanización global y la tendencia actual a que las ciudades presenten un complejo de centralidades "de lugar". Sin duda, en las alteraciones de la Historia del Planeamiento son fundamentales las condiciones especiales de la sociedad contemporánea, con casi el 80\% de sus miembros viviendo en entornos urbanizados. Pero junto a ello está el extraordinario aumento de la producción de "lugares" de nueva invención bajo las más diversas formas: lugares de ocio, centros comerciales temáticos, renovación de escenarios históricos, etc. Esta tendencia dominante provocó cambios en las actitudes de planificación, consideradas históricas frente a sus reivindicaciones globales. Sin embargo, muchas de las cuestiones teóricas innovadoras que ahora se vinculan al concepto de lugar no se han examinado a fondo en el ámbito de la planificación hasta ahora. Además, el concepto está absorbiendo ahora los intereses de investigación de otras disciplinas, lo que hace que se introduzcan importantes contribuciones a sus aspectos fundacionales, estableciendo así una condición transdisciplinar a su esencia. De hecho, la teoría de la planificación parece estar ya madura para "sustituir" su concepción predominante del lugar. Este artículo pretende sugerir algunas de las direcciones a seguir en ese intento. Metodológicamente, seguirá las direcciones marcadas por tres tipos de conflictos generados por las variaciones: controversias, contrastes y desafíos.

Abordar las variaciones en términos de controversias implica darse cuenta de la dualidad de los papeles que los lugares pueden desempeñar en los comportamientos de la sociedad actual: uno funcional y otro existencial. De hecho, para algunos estudiosos, los nuevos lugares inventados de hoy en día se apropian como nuevos lugares de urbanidad, lo que lleva a pensar que estamos al borde de una situación en la que la percepción del lugar puede influir en la percepción de la "urbanidad" -la urbanidad entendida como esa cualidad única que transmiten las ciudades a sus ciudadanos en términos de comunicación y sociabilidad, lo que en última instancia conlleva nuevas formas de disfrutar de la urbanidad que ofrecen las ciudades. Los contrastes asociados a las variaciones sacan a la luz una dualidad presente en la propia disciplina de la Planificación. Anteriormente, la disciplina consideraba que el sentido del lugar derivaba exclusivamente de las prácticas de la sociedad, surgiendo de ellas como una construcción social, mientras que hoy, además de ser una construcción social, el lugar se considera también una construcción económica. Esta es una condición que a veces exacerba los contrastes sociales inherentes, produciendo ciudades salpicadas de fragmentos de excepción que se cree que actúan sobre la estructura urbana como factores desintegradores que evidencian las diferencias latentes. Por último, enfocar las variaciones en términos de sus retos dirigirá la atención hacia las decisiones de planificación que los administradores de las ciudades deben tomar cuando deciden embarcarse en el juego del placemaking + placemarketing -o no-, un reto al que las ciudades se ven cada vez más obligadas a adherirse, a menudo a riesgo de comprometerse con exigentes prácticas competitivas.

Palabras clave: Teoría del lugar, Urbanidad, Historia de la planificación, Percepción ambiental.

\section{CONTRADICTIONS IN THE MEANING OF PLACE IN PLANNING HISTORY}

The concept of place has a long history in Planning and, accordingly, has experienced a good number of variations along its trajectory in the area's disciplinary contents. These variations, sometimes more sometimes less, provide grounds for a diversity of arguments, occasionally interpreted as controversies in the meanings attributed to place in Planning. In Modernism, Architecture and Urbanism constructions were valued as having a potential for "....modernizing society, and were believed to become 
agents for social change and economic development" (Castello 2005: 100). Places would exercise a central role in this understanding because, in the idealized lines expressed mainly in European modernist thinking, a place should serve people in their daily functional needs and reward people with existential experiences in their daily lives. In this context, the ancient Greek agora ${ }^{1}$ soon became an irresistible template in which to model the planning of what could become a place.

Having established the agora as a suitable metaphor for the ideal functional and existential place they wanted to introduce in a modern town, planners also determined the establishment of an initial contradiction that would become a conflictive companion constantly haunting the idea of place in Planning since then and all through its evolution in the discipline. The metaphorical figure of the agora, at least in theory, worked for both public and private designs. However, throughout Planning history, there seems to have been a general agreement among planners that place is a public space in which people meet. Truly, this has been almost a truism in the profession and easily accepted among other professionals such as architects, engineers, landscape designers, geographers, psychologists, philosophers, and the like. As for what a public space is, in turn, far from a consensus, what we have is a series of particular readings, conferring to the topic a status of considerable dissent. To start with, one could initially argue whether a place would be exclusively a plural public space where people meet: And what about a place as a special space for a single individual? Furthermore, as acutely observed by the team of Dutch researchers led by Tom Avermaete, the legitimate definition of the public space has been officially introduced only by means of the 'Declaration of the Rights of Man and of the Citizen' during the French Revolution in 1798. This document "... established legal rights of property for the first time...Paradoxically the declaration included a definition of the private domain and... This description of the private domain is also the first official definition of a modern public domain" (Avermaete et al. 2009:25).

As it is, the straight classification public space seems unsatisfactory and becomes often questioned. The Dutch researchers, for example, find it more appropriate to use the expression public sphere instead, a point that had been originally made by Scott-Brown in the late 1980s, when she preferred to designate the public sector seen in physical terms as the public realm, observing that the public realm itself would include a further differentiation between public and civic. Avermaete favours the expression public sphere and contrast it to the term public domain understanding that "Three terms form the background to the debate on the public sphere: 'modernization', 'modernity', and 'modernism'” (Avermaete et al. 2009: 19).

\footnotetext{
1 "In ancient Greek cities, an open space that served as a meeting ground for various activities of the citizens.... The name... connotes both the assembly of the people as well as the physical setting; ... regarded as a typical feature of their life: their daily religious, political, judicial, social, and commercial activity...". Encyclopadia Britannica. Retrieved March 11, 2010, from Encyclopædia Britannica Online: http://www.britannica.com/EBchecked/topic/9404/agora
} 
This triptych is in fact what lies behind most interpretations given to the changes experienced in the concept of public space along Planning History.

As a matter of fact, Planning sees an intrinsic contradiction in the public meaning attributed to the concept of place: though traditionally idealized as public spaces, places have been often generated as private spaces all along Planning history. This is an old contradiction and goes back to the times of the agora in the Homeric times of ancient Greece, which in all likelihood, as mentioned before, gave origin to the idea of place in Planning. "Primarily the agora is an open space, publicly held and occupiable for public purposes... in its primitive state, the agora was above all a place for palaver; and there is probably no urban market-place where the interchange of news and opinions did not, at least in the past, play almost as important a part as the interchange of goods", as Lewis Mumford (1973:175-176) so interestingly teaches us. Initially materialized as a spatial void enclosed by buildings or colonnades, the Greek agora evolved towards becoming a space situated at the gates of the city, accommodating many functions, including market transactions - activities obviously pertaining to the private domain. Also Roman times demonstrate that to attribute the notion of a public space as the more likely location for a place is no more than a relative idea. Indeed, the Roman forum, in essence, the symbol of the union of various tribes that composed ancient Rome, was the "...foundation of a common market-place (the Forum), with a place of assembly or comitium..." (Mumford 1973: 257). This 'place' - the Roman forum - soon germinated from an open space to a complete set of buildings offering a variety of enclosed central functions serving the whole region, when '...ever larger crowds would be drawn to the centre for shopping, for worship, for gossip, for taking part, as spectators or actors, in public affairs or in private lawsuits" (Mumford 1973: 258). This description somehow coincides with the idea we now have a about a central place, but, once again, we see the understanding of a 'public' space contradictorily interspersed with 'private' activities inside its enclosure.

\section{CONTRASTING PLACES IN PLANNING HISTORY}

As a general rule, the contradiction mentioned in the previous section can be accredited to variations in the attribution of values to the idea of place. Therefore, place could be successively valued as the "...response of city form to accommodate the social and political order of the polis" (Whitaker 2005: 7) as in ancient Greek agora, in which place performed a strong civic role; or as in the medieval (private) Market Place, valued as the gathering (public) space for all the inhabitants of the town; or as in the nineteenth century modernity postulated by social utopians like Fourier, who proposed buildings for public purposes in his privately built Phalanstère - places where people could meet other people - such as community dining halls, nurseries, libraries, laundries, attributing an optimistic socializing value to the idea of place; or at the ending of that century, when prevailed the idea that city planning was to be valued 
as civic planning, where the design of places would be purely a matter of civic design: "Planners and designers of the City Beautiful movement focused their attention on the public ceremonial parts of the city and Beaux-Arts schools of architecture offered programmes in 'civic design"” (Scott-Brown 1990: 21), and the representational value of places took place mainly in civic spaces such as cultural centres, town halls, community centres, and the like; or to finally arrive to the latent modernity of the twentieth century Modern Movement where place, on the one hand, starts to be valued as a powerful means to guide towards a new 'public sphere' modelled by egalitarian aims and capable to encourage a politically active citizenship [and the imposing emblematic civic space known as the 'Praça dos Três Poderes' (The Three Powers Square) in Brasilia provides a fruitful example of that]; and, on the other hand, achieves the value of operating as an all comprising functional centre (including both public and private facilities) for the neighbourhood units of numerous New Towns projects, such as in Runcorn New Town, near Liverpool.

The transition from late twentieth to early twenty-first centuries sees quite expressive changes in the values attributed to places, consecrating the contrast between the understanding of place as a social construction and place as an economic construction. As a consequence, a good number of written manifestations based on this contrasting values start to be produced. Among the optimistic ones, the works by William H. Whyte ${ }^{2}$ in the USA, mainly in New York, and Steven Carr ${ }^{3}$ and colleagues, became paradigmatic for having introduced an innovative look at urban spaces that became known as 'privately owned public spaces' (Kayden et al. ${ }^{4}$ ), combining public incentives conceded to private stakeholders provided they left places for public uses in their constructions. And among the pessimistic, one can mention the famous literary work organized by Michael Sorkin", also in New York, focusing on the "new American city and the end of public space'. In fact, the new century opens with considerations varying from a high pragmatic orientation given by authors such as François Ascher $\left(2008^{6} ; 2004^{7}\right)$, who issues unusual propositions for reducing the public-private contrast about places through new mechanisms for planning urban places in contemporary cities; to a bitter, though realistic, set of acid criticisms about today's public places in global cities, such as the ones disseminated by the well known polemist Rem Koolhaas, who practically claims that the contrast is over in face of the demise of the public spaces in

\footnotetext{
${ }^{2}$ WHYTE, William Hollingsworth (1990). The Social Life of Small Urban Spaces. Washington DC: The Conservation Foundation, 8th ed.

${ }^{3}$ CARR, Steven, FRANCIS, Mark, RIVLIN, Leanne and STONE, Andrew (1995). Public Space. Cambridge: Cambridge University Press, $2^{\text {nd }}$ printing.

${ }^{4}$ KAYDEN, Jerold; New York City Department of City Planning; Municipal Art Society of New York (2000). Privately Owned Public Space: The New York City Experience. New York: Wiley.

${ }^{5}$ SORKIN, Michael (ed.) (1997). Variations on a Theme Park. The New American City and the End of Public Space. New York: Hill and Wang, (8th ed.).

${ }^{6}$ ASCHER, François (2008). Les Nouveaux Compromis Urbains. Lexique de la Ville Plurielle. Éditions de 1'Aube.

${ }^{7}$ ASCHER, François (2004). Les Nouveaux Principes de l’Urbanisme. Paris : Éditions de l'Aube.
} 
cities, since provocatively, in his view, "Shopping is arguably the last remaining form of public activity" (Koolhaas et al. 2001: 125).

On top of that, the new millennium posits a new polemic, seemingly only in its initial stages yet. Place's traditional value of bringing people together may be facing a tricky trial, at least in terms of assembling people in spatial venues - public or not. This is so because the role played by mass media on the public sphere is contributing to diminish the spatial importance of the location of place. In fact, this consideration had already been registered in the previous century, by authors such as Jürgen Habermas and Hannah Arendt, who see the mass media as potentially capable to distribute information that will become shared by the public as a whole. In this line of thought, mass media such as newspapers, books, periodicals and television are seen as creating an image of a public locus and hence, are determinants of a public sphere all by themselves. Moreover, in the present century, an entirely new element adds new heat to the discussion: the role of the Internet comes into scene, an information technology that "...has created the conditions for a public sphere that no longer has a fixed, ascertainable location, like the surface of the public square or the editorial page of the newspaper... a multitude of people can nowadays be mobilized in a short time, a phenomenon that has been called 'adhocracy"' (Avermaete et al. 2009: 42). Needless to say that this embryonic polemic will enormously entice the public-private place's contrast, with the accessibility to the new information technologies and the 'location' of the new immaterial social places predominantly transformed into a matter of economic power in the battlegrounds of the political arena.

\section{THE CHALLENGES POSED TO PLANNING PLACES}

The biggest challenge posed to planners today is to plan places capable to fulfil two concurrent goals and to assist people in two cumulative ways: places that serve people in their daily functional needs; and places that reward people with existential opportunities in their daily lives. This is not an easy task, though, and has been encouraging some inspiring theoretical studies on the matter.

In the repertoire of place in Planning history it is not difficult to identify the presence of two types of places, what is a clear indication of the existence of a sort of 'typology' of places: places that are socially constructed; and places made through economic drives. Ultimately, these two 'types' can merge and generate one single place. Though an economic construction in its origin, a place can derive a social construction through its progressive public appropriation; and vice-versa. In other words, even if we can notice an intrinsic contrast between them, they can be basically considered a single unit, although this imposes an enormous challenge in Planning terms.

It is true that different Planning currents support either one or the other type. But it is also true that today, in contemporary Planning, the duo seems to be increasingly accepted. Of course, this must be 
understood as an innovative theoretical approach to the concept of place in Planning, with some authors regarding it as a 'postmodern' focus to the topic (e.g.: Ellin ${ }^{8}$; Nesbitt ${ }^{9}$ ). Others see it as an adaptation to modern time's societal behaviours that demand a thorough variation in conceiving what a place might be in actual times (e.g.: Carmona and Tiesdell ${ }^{10}$; Castello ${ }^{11}$ ). Whatever the case, the novel approaches towards the concept may provide a satisfactory explanation for the conflicts the concept is acknowledged to raise in the course of contemporary Planning, conflicts manifested either through contradictions or contrasts, as discussed in the previous sections.

The acceptance of this combination, however, has not been as smooth as it may seem. The construction of new places along the lines of mutual purposes - social and economic designs accompanied by functional and existential roles - has not been easily accepted by cultural critics. The usual complains point out to a certain distortion on the side of the Planning proposals, seemingly inclined towards privileging effects that would weigh more beneficially to the economic side of the equation, and leave the social facet relatively uncovered. Nevertheless, there are today lots and lots of built examples that vehemently contradict this interpretation, producing places 'cloned' upon the characteristics of existing places of urbanity, 'invented' (Carmona el al. ${ }^{12)}$ places that make an intelligent use of these characteristics knowing how to accurately 'clone' them in the direction of reaching a competent result. Interestingly, a good number of these invented places end up by becoming effectively integrated to the city's repertoire of places of urbanity, which will offer new kinds of existential experiences for the population, experiences more adequate to the present behaviours of contemporary society and more akin to their present aspirations. Surely, it has become razor-clear now that there are important consequences of this new way of seeing places in Planning on sociological, psychological and also philosophical grounds. The concept of place is playing a key role in Planning today, not only from its extraordinary influence in phenomenological matters, but also, in view of the excellent economic repercussion that many new places have achieved worldwide. Unsurprisingly, this last accomplishment is of crucial significance for today's globalized trends of urbanization, and asks for a necessary look at the major urban-architectural and planning-management operations it involves.

There are two fundamental constituents worth mentioning in the challenging process of planning places today: Placemaking and Placemarketing. The dual action of these two factors can explain many of

\footnotetext{
${ }^{8}$ ELLIN, Nan (1999). Postmodern Urbanism. Revised edition. New York: Princeton Architectural Press.

${ }^{9}$ NESBITT, Kate (ed.) (1996). Theorizing a New Agenda for Architecture. An Anthology of Architectural Theory $1965-1995$. New York: Princeton Architectural Press.

${ }^{10}$ CARMONA, Matthew \& TIESDELL, Steve (eds.) (2007). Urban Design Reader. Oxford: Architectural Press.

${ }^{11}$ CASTELLO, Lineu (2010). Rethinking the Meaning of Place. Conceiving Place in Architecture-Urbanism. London: Ashgate (forthcoming May 2010).

12 CARMONA, Matthew; HEATH, Tim; OC, Taner; TIESDELL, Steve (2003). Public Places - Urban Spaces. Oxford: Architectural Press.
} 
the accomplishments contemporary planning professionals are achieving in their professional efforts. In their placemaking process, planners carefully make sure to strategically include sophisticated placemarketing operations that will guarantee a highly successful acceptance of the newly invented places. This seems to be the case, for example, with places designed and promoted by entrepreneurs - even those acting unexpectedly as 'planners' like, to pick an example at random, the Disney Corporation - who have built an extraordinary collection of invented places, all of them bringing about remarkable popular social acceptance as well as worthwhile economic returns. Moreover, nowadays, entire cities are seen as 'theme places' (Judd and Fainstein ${ }^{13}$ ), with their old historical areas revamped and gaining unusual revitalization and global competitive force; and one can easily point to satisfactory examples of invented places coming from all corners of the world, be it in Europe, Asia or Oceania, beyond the Americas (Figs. 1-10).

Thus, the two predominantly contrasting types of places in Planning can be seen as moving towards a progressive merging, so as to act jointly as a new force aiming to enhance people's quality of life in the built environment; and bringing favourable economic returns in pragmatic terms. Therefore, the infiltration of economic deeds into the pure sociological intentions usually ascribed to the construction of place in Planning are bringing, in the end, satisfactory outcomes, somehow demanding a sort of 'replacing' of the position of place in the Planning attitudes of today.

\section{CONCLUSION}

The concept of place is a crucial issue in the area of Planning since it deals with two basilar factors associated to the discipline's fundaments: people and space. More importantly, it influences the existential quality of people in space.

Conflicts the planning of places has been dealing with along Planning history have proved quite controversial, due to the distinctive gazes employed in the valuing of the concept within the discipline. Some of these distinctive views have incurred in the issuing of controversial arguments manifested through contradictions, contrasts and challenges to the area which, ultimately demand a 'replacing' of the concept within the profession's paradigms.

Basically, the contradictions refer to the relatively conflicting understanding of the place's concept playing a functional task, as opposed to place performing an existential role in contemporary society's daily life. Certainly, this derives from the traditional dichotomy public-and-private attributed to place, as debated in the paper's initial section. The indetermination provoked by this duality, most probably inherited from the interpretation of place as a space similar to that represented by the ancient Greek agora - in which it enjoyed a status of combining both civic and commercial deeds - has conduced place to a

13 JUDD, Dennis \& FAINSTEIN, Susan (1999). Global Forces, Local Strategies, and Urban Tourism. In JUDD, D.; FAINSTEIN, S. (eds.). The Tourist City. New Haven / London: Yale University Press, p.1-17. 
present acceptance as a semiprivate or a semipublic urban space. To explain this, it seems important to acknowledge the extraordinary importance places play in contemporary society human existential matters, rendering quite admissible to incorporate the understanding of places within the profession as moving from the previous strict functionalist focus it had so far, to a new phenomenological approach. In other words, the concept of place progressed from its former status of functional areas, to a well-deserved positioning as a concept of existential concerns.

As for the contrasts, it seems that in brief, the conflicts can be summarized as a dispute between the social and the economical virtues of place (and it has both). Ideally, in the utopian thinking of many planners - especially to those following more closely the Modernist Urbanism principles - place could only be generated as a social construction. The progressive and unimagined drastic changes experienced in society's behaviours in postmodern times, have certainly added to unimaginable changes in the conceptualization of place. Understandably, to design a social construction was certainly a heroic, if not totally unattainable, effort planners had to face when confronted to the modern making of mid-twentieth century places. Furthermore, conflicts raising from the competent criticisms issued by parallel disciplines such as, for example, Environmental Psychology, Sociology, Geography and Anthropology, brought a discomforting disappointment with places designed at that epoch. In this context, it was quite an easy task to introduce economic and management features to try to encourage the planning of places to make them really work. The last quarter of the century saw, then, a growing concern with the construction of invented places. More importantly yet, the epoch evidenced the escalating success in both, economic and social terms the invented places were achieving. As a consequence, the economic returns arising out of the postmodern practices adopted in the construction of place, added to the predictable sociological returns formerly associated with the utopia of place, resulted in a planning tactic frankly practiced in the history of place in Planning.

Finally, at the actual stage of the place concept in Planning, it seems that another line of conflicts starts to worry the profession, conflicts this time, wide enough so as to interfere in matters more akin to the city's administrative and governmental spheres. Unusual procedures afflict today's planning of places and, among them, two seem to be particularly trying, one demanding from the urban government the engagement of the city in practices typical of the so-called 'creative economy' (Florida ${ }^{14}$ ); and other, introducing to planning methodologies unexpected techniques formerly more commonly employed in competitive marketing operations. Or, put another way, in current times, city administrators need to add to the critical challenges their copious amount of daily problems inflict upon their decision-making

\footnotetext{
${ }^{14}$ FLORIDA, Richard (2004). The Rise of the Creative Class: And How It's Transforming Work, Leisure, Community and Everyday Life. Cambridge, MA: Basic Books.
} 
processes, the additional burden of having to cope with the challenge posed by the fierce competition globalized urbanization constantly impinges upon their cities today.

Accordingly, it is now rather common to find planners challenged by operations of placemaking + placemarketing, applying an entirely new approach to planning places which translates a global contemporary planning style tentatively bringing together private and public sectors activities. The reasoning behind this engagement is apparently quite clear. Former operations of placemaking adopted in the profession, especially those that included the rigid proposals of modernist times, brought about disappointing failures, giving way to the creation of derogative expressions such as the hideous 'placelessness' (Relph $1976^{15} ; 1996^{16}$ ). Contrarily, later day placemaking tactics have succeeded to produce admirable exemplars of good planned places, pointing, for sure, to planning's adoption of innovative strategies of making places. In the same direction, another practice also foreign to the usual planning of places which has been thoroughly adopted by contemporary planners is the branding of places (Anholt $2004^{17} ; 2010^{18}$ ), somehow understood as a metaphor for the competition established by the worldwide creation of tempting places, struggling to attract and to entertain people in an exciting assortment of alluring areas spread over the urban landscape of global cities. A most likely procedure for Planning in this case is to create a brand for the place, monitor the growth of its merits, and assure that an adequate marketing feedback is kept at all times. Planners do indeed acknowledge the extraordinary importance the making of a place means for today's planning actions. This excerpt from a publicity campaign for a new urbanization in the state of Florida (USA) is self explicative on this respect: 'For those of us in the business of creating new places .... It's been said that great sculptors have the ability to unlock the image held inside a block of stone. In a sense, that's what great planners do as well. They strive to unlock the place held inside a piece of land'. A plaque in a place purposely built in Brisbane, Australia, adds further evidence to the benefits Planning attributes to the role of placemaking + placemarketing in our days (Fig.11). It dedicates the place to its creator, Trevor Reddacliff (adequately an architect, town planner, developer and businessman), for his vision to ' ... introduce the city to international design and to renew and enliven our cultural outlook. ...Reddacliff Place is named in honour of his significant contribution to making Brisbane a livable, culturally rich, socially diverse, egalitarian city".

In sum, the place of place in Planning has occupied different premises along History. It has been located as a distant agora or a remote forum transplanted to the day-to-day life of a modern city; has been seen successively as a medieval market place or a symbolic civic cuore; as representing the civic areas of

\footnotetext{
${ }^{15}$ RELPH, Edward (1976). Place and Placelessness. London: Pion.

16 RELPH, Edward (1996). Reflections on Place and Placelessness. Environmental \& Architectural Phenomenology Newsletter, vol.7, №3, Autumn, p.15-18.

17 ANHOLT, Simon (2004). Brand New Justice. The Upside of Global Justice. Oxford: Elsevier.

${ }^{18}$ ANHOLT, Simon (2010). Places. Identity, Image and Reputation. Basingstoke (UK) : Palgrave Macmillan.
} 
the industrial times or the functional areas of the modernism times; as offering a socializing venue for inspiring social contacts; as acting as a behavioural setting in psychological grounds; as providing a perfect locus for the existential hedonism ethos of the actual consumption society; to be finally positioned as a profitable source of economic returns; and to portray an ideal scene for the establishment of a brand in city-marketing ventures.

In face of this, one cannot help but to conclude by wondering: and what would possibly become the meaning of place tomorrow? 


\section{REFERENCES}

Avermaete, Tom; Havik, Klaske; Teerds, Hans (2009). Architectural Positions. Architecture, Modernity and the Public Sphere. Amsterdam: SUN Publishers.

Castello, Lineu (2005). Costa, Lúcio. In Roger Caves (ed.). Encyclopedia of the City. London/New York: Routledge, p. 99-100.

Koolhaas, Rem \& Harvard Project on the City (2001). Shopping. In Koolhaas, R. et al. Mutations. Bordeaux, France: ACTAR-Arc en Revê Centre d'Architecture, p. 124-184.

Mumford, Lewis (1973). The City in History. (originally published 1961). Harmondsworth, Penguin Books.

Scott Brown, Denise (1990). The Public Realm. The Public Sector and the Public Interest in Urban Design. In Scott Brown, D. (Org.). Urban Concepts. London: Academy Editions, pp.21-29.

Whitaker, Ana Maria (2005). Agora. In Roger Caves (ed.). Encyclopedia of the City. London/New York: Routledge, p. 7.

This article has been originally presented by his author at the 14th International Planning History Society Conference Urban Transformation: Controversies, Contrasts and Challenges, ITU Faculty of Architecturet, Istanbul, Turkey, July 2010 


\section{ANEXOS}

Fig. 1- Italian 'piazzas', such as Piazza Navona, are acknowledged as genuine examples of spontaneously built places, currently enhanced by intelligent marketing policies

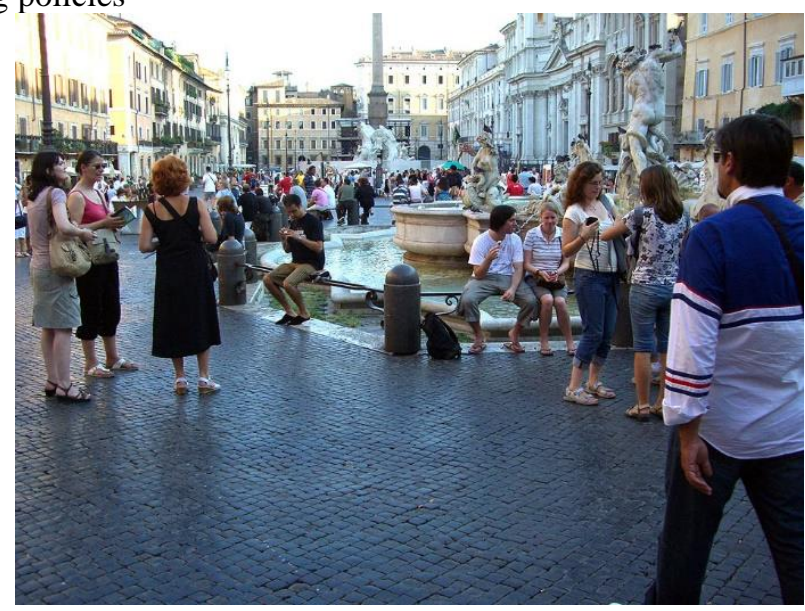

Fig. 2 - Istanbul, Turkey, is famous worldwide for its exquisite bazaars, such as the Gran Bazaar in the central area

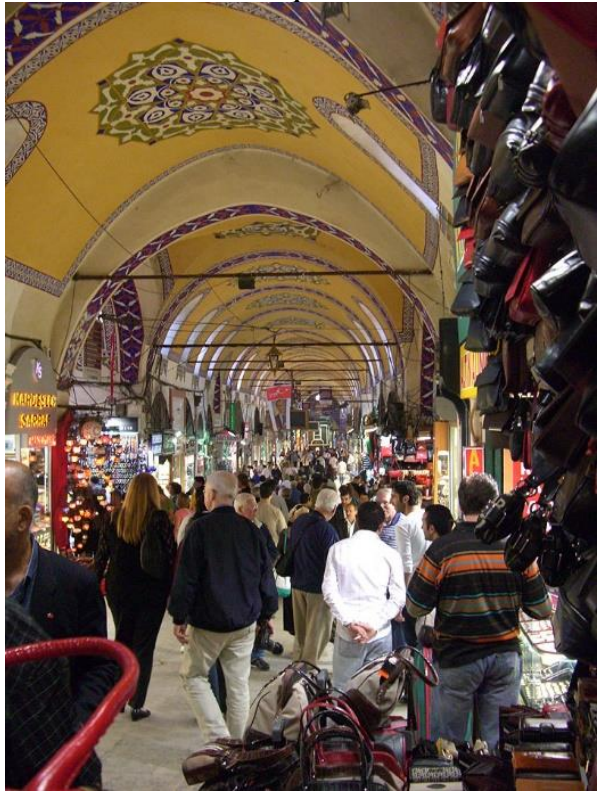

Fig. 3 - Istanbul, Turkey. Taksim is an extremely lively place attracting people from all corners of the city

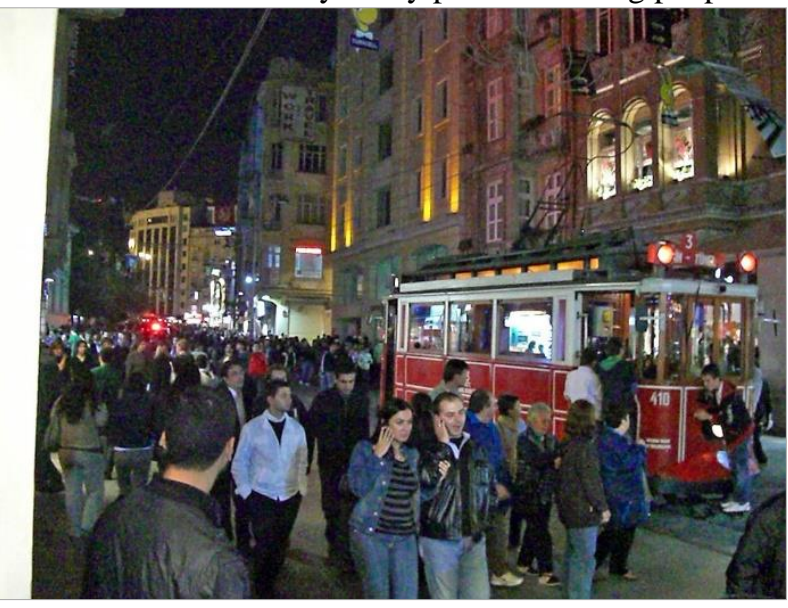


Fig. 4 - Also in Istanbul, the Maslak area displays an array of luxury malls carefully designed and marketed as invented places

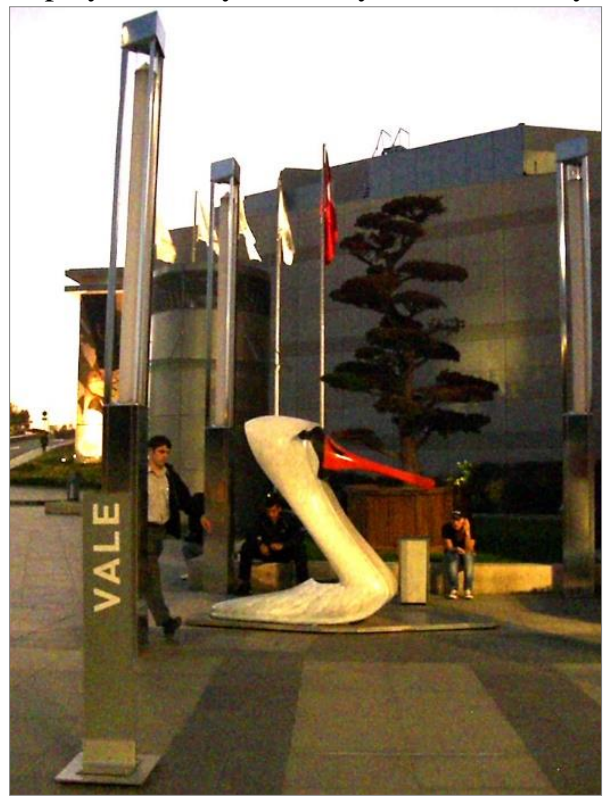

Fig. 5 - Malls in Dubai, United Arab Emirates are created as fantastic places alluring thousands of fascinated visitors

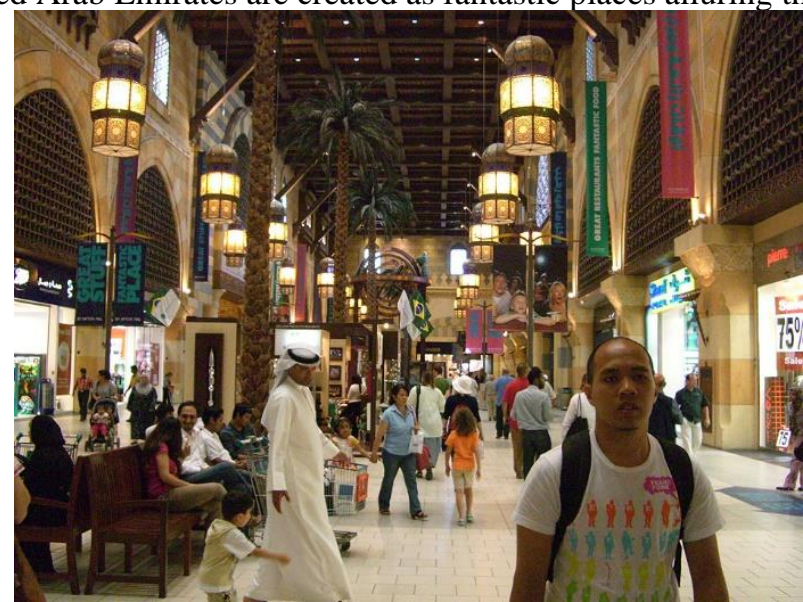

Fig. 6 - Singapore. An unusual and continuous succession of malls aligns as a row along a remarkable single avenue, the famous Orchard Road

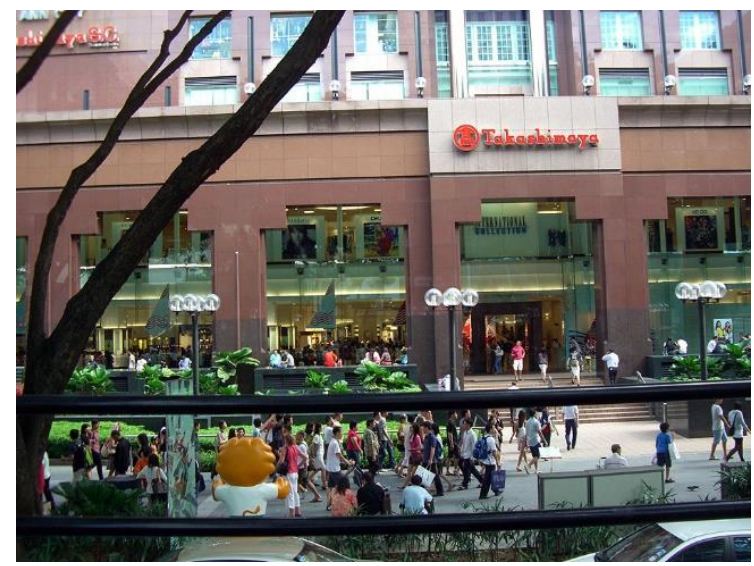




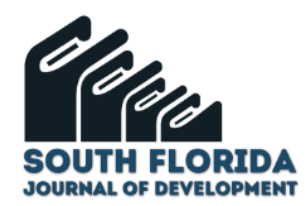

Fig. 7 - Brisbane, Australia. South Bank is a wonderful invented place gathering cultural, recreational, educational, commercial, sports and residential activities, already valued as a legitimate place of urbanity

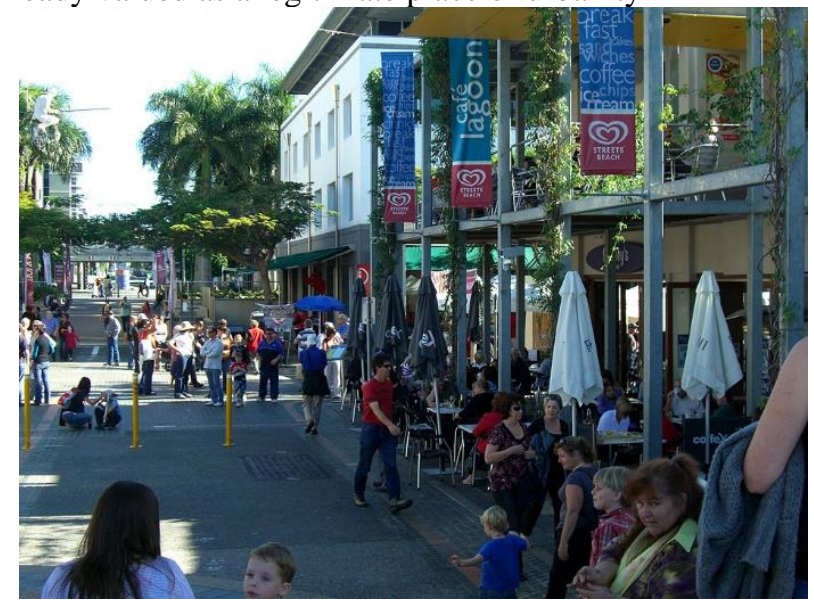

Fig. 8 - Lapa is one of the most popular places in Rio de Janeiro's (Brasil) historic central area, and has been presently revivified through tourist marketing actions

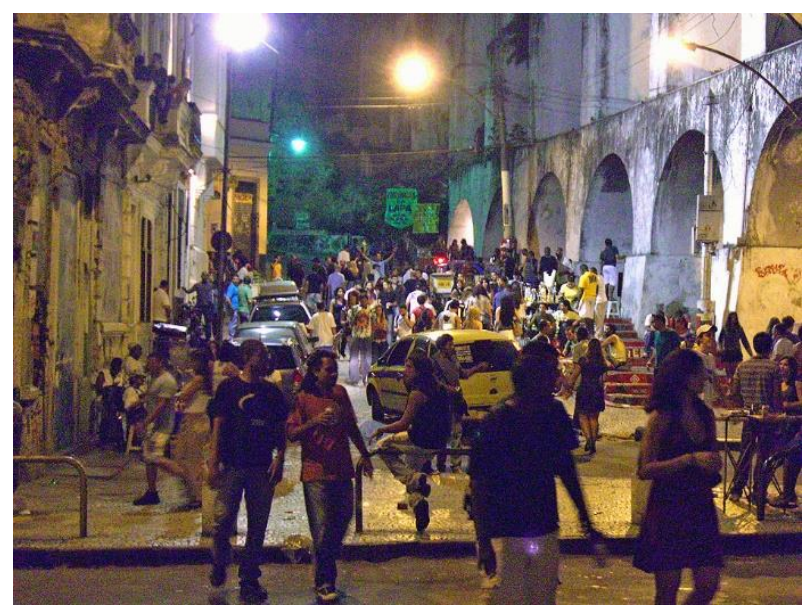

Fig. 9 - The Central Market in São Paulo, Brasil, is a typical meeting place filled of urbanity that merges business, leisure and social activities in balanced proportions

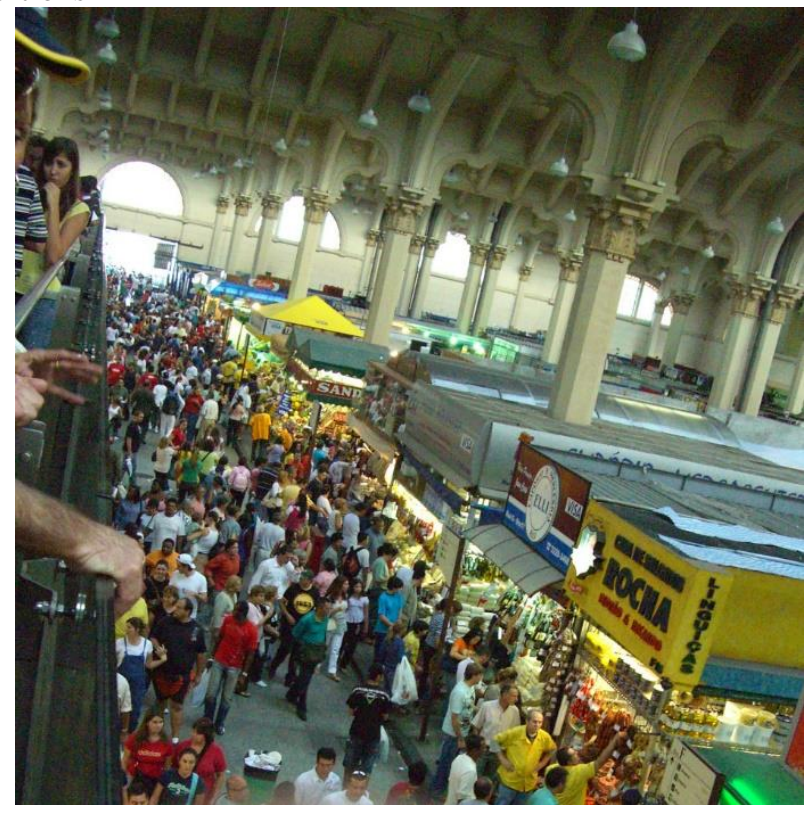


Fig. 10 - Union Square in San Francisco (USA) is still an appreciated place where one can fully enjoy the feeling of urbanity

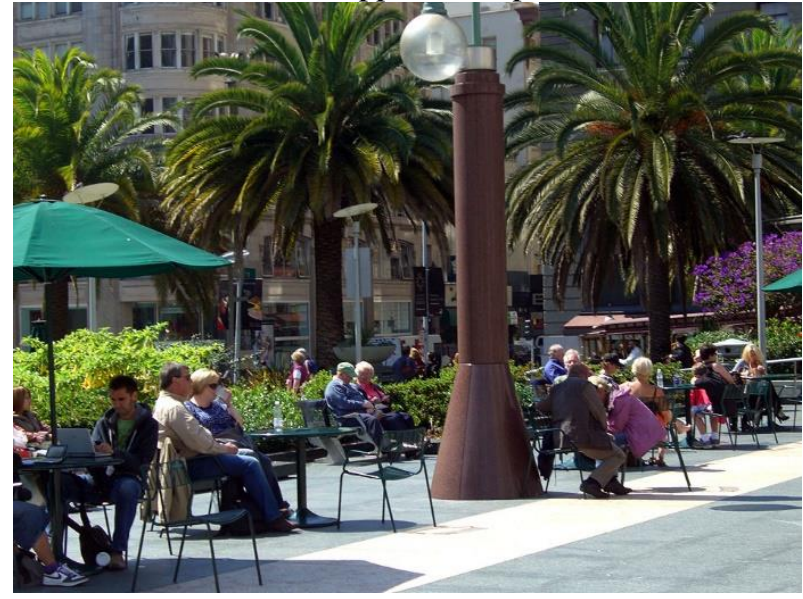

Fig. 11 - Plaque at Reddacliffe Place, central Brisbane, near Queen Street Mall, celebrating the creation of a place

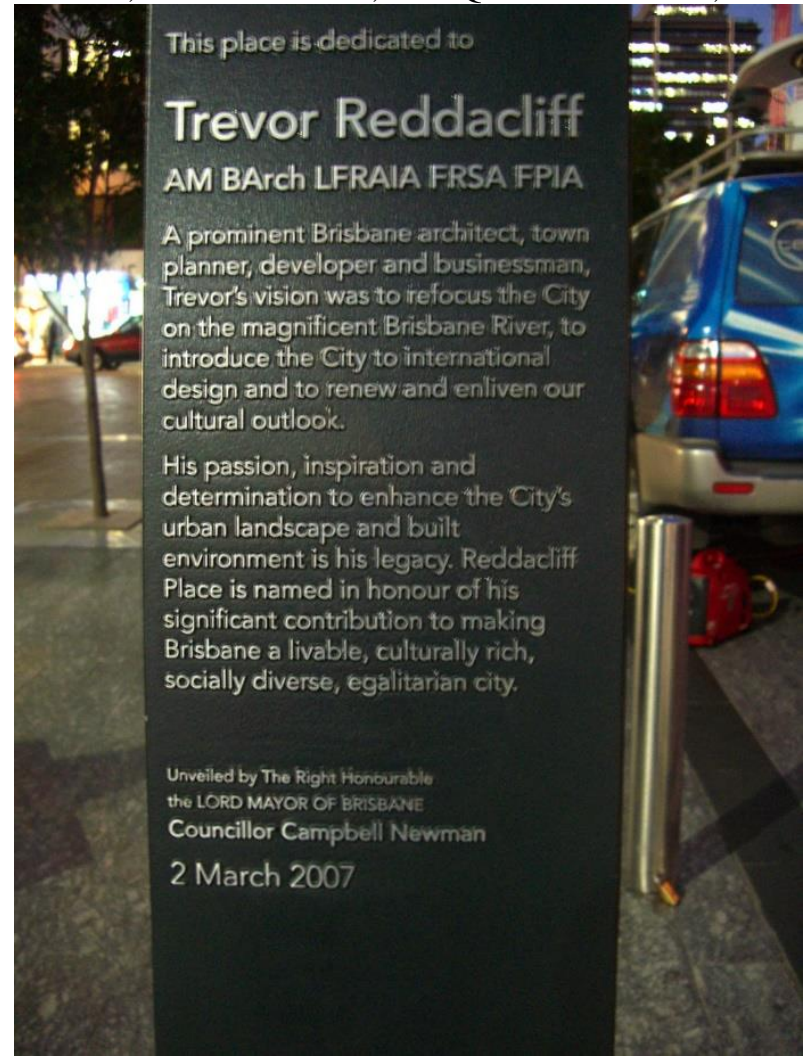

